\title{
Report on the Undergraduate Awards Global Summit (1)
}

\author{
JACQUELINE L.W. WILLIAMS
}

Jacqueline Williams was the overall winner in the Law category of the 2016 international Undergraduate Awards for her paper, 'The Enforcement Regime of the Australian Securities and Investments Commission (ASIC) under Chapter 7 of the Corporations Act: Reform Required', and attended the Prize Ceremony and Global Summit in Dublin, Ireland. A summary of her paper has been published in The Undergraduate Journal.

Marking a fantastic conclusion to my undergraduate studies, within 24 hours of finishing my final law exam I was sitting on a plane to Dublin, Ireland, to attend the Global Summit of the 2016 Undergraduate Awards. It was quite surreal to participate in the Summit, this year with over 150 attendees from around the world who had also been named as winners or highly commended entrants in their categories. All the participants were brimming with enthusiasm-eager to share their own research, and curious to hear about the passions and future plans of others. It was a privilege to attend the Summit, which proved to be thought-provoking and incredibly enjoyable.

The Undergraduate Awards is the world's largest pan-discipline undergraduate awards program. In 2016, there were over 5,500 submissions from 244 institutions across 41 countries. The diverse range of papers across the 25 categories was revealed at UPresent on day one of the Summit, when a number of attendees presented a summary of their papers. It was fascinating to hear from students across the world proposing innovative ideas to challenging topics-from analysing the economic, environmental and social benefits of solar panels in impoverished areas, to investigating the use of $3 \mathrm{D}$ printers for medical training purposes, to critiquing justifications of a human right to democracy, analysing the political consequences of American drone strikes in the Middle East, and more! The presentations were inspiring and stimulated passionate conversations throughout the rest of the Summit.

As well as participating in workshops and discussions with each other during the Summit, we were very fortunate to hear from a number of international guest speakers. I particularly enjoyed the Colloquium, where we heard about the lives, careers and passions of a range of prominent academics, humanitarians, physicians, diplomats and business directors. Speakers included Stephanie Duhaime, who established Canada's diplomatic mission in Iraq; Dr Rhona Mahony, the first woman to be 
named Master of Ireland's National Maternity Hospital; Rob Mather, who founded the Against Malaria Foundation; and Professor Ian Robertson, a Co-Director of the Global Brain Health Institute.

All of the events were held at historic locations around Dublin. On the opening evening, we dined at the Smock Alley Theatre, one of Dublin's oldest theatres. The Colloquium was held at the picturesque Farmleigh House, a former residence of the Guinness family and now Ireland's official state guesthouse. For the Gold Medal Presentation Ceremony, we were welcomed to City Hall (built in the 1770s and centre of the British Government in Ireland until 1922) by Dublin's Lord Mayor Brendan Carr.

At the Presentation Ceremony, the 25 Global Winners were each presented with a gold medal by the Guest of Honour, and first African-American woman to travel into space, Dr Mae Jemison. We also heard from Hugh Tinney about the life of Sheila Tinney, whose portrait was engraved on our gold medals. Sheila was a trailblazing Irish mathematician and physicist, who collaborated with the likes of Albert Einstein and Erwin Schrodinger in her work on quantum physics.

Following the Presentation Ceremony, we attended a Harry Potter-esque dinner at St Patrick's Cathedral. Entering the Cathedral was breathtaking, with beautiful lights illuminating the tall pillars and archways, and long tables stretching along the nave of the Cathedral. It was a lovely evening with delicious food and great company. I even discussed life in space with Dr Jemison!

The Undergraduate Awards Global Summit was an unforgettable experience. I did not imagine that I would get the opportunity to attend an international summit on the other side of the world when I was writing my paper about the Australian Securities and Investments Commission's (ASIC) enforcement powers for the law elective 'Financial Markets and Takeovers'.

ASIC is Australia's corporate, markets and financial services regulator. Established by the Australian Securities and Investments Commission Act 2001 (Cth), ASIC performs most of its work under the Corporations Act 2001 (Cth). ASIC's regulatory functions are critical to support the stability and effectiveness of Australia's financial markets. In particular, ASIC seeks to facilitate the fair and transparent performance of Australia's financial services market, while supporting the confident and informed participation of investors and consumers in this system. ${ }^{1}$ ASIC is required to administer and enforce the law effectively and with minimal procedural requirements. ${ }^{2}$

\footnotetext{
Australian Securities and Investments Commission Act 2001 (Cth) ss 1(2)(a)-(b).

Ibid., ss 1(2)(d), (g).
} 
In 2014, the Senate Economics References Committee stated that:

ASIC's enforcement role is one of its most important functions. ASIC needs to be respected and feared. It needs to send a clear and unmistakeable message ... that ASIC has the necessary enforcement tools and resources and is ready to use them to uphold accepted standards of conduct and the integrity of the markets. ${ }^{3}$

In light of the committee's remark, my paper analysed the enforcement options available to ASIC under Chapter 7 of the Corporations Act, focusing on the civil penalty provisions. As a hybrid between criminal and civil sanctions, civil penalty provisions play an important role in ASIC's enforcement regime and assist ASIC to uphold the integrity of the financial market. However, recent cases of corporate wrongdoing have demonstrated that ASIC's civil penalty powers under the Corporations Act fall short when compared to the legislative schemes of other Australian and international financial market regulators.

In order to effectively deter and punish corporate wrongdoing that adversely impacts financial markets and confident market participation, my paper argued that ASIC's civil penalty powers under Chapter 7 of the Corporations Act need significant reform. Broadening the range, and strengthening the level, of civil penalty provisions available to ASIC would promote consistency with other regulators' powers, and enable courts to impose penalties adjusted to the seriousness of corporate wrongdoing. Clarifying the rules governing procedural and evidential requirements for civil penalty proceedings would further support the envisaged role of civil penalty powers within ASIC's enforcement regime. Strengthening the civil penalty regime would enable ASIC to deliver better market outcomes by improving the cost-effectiveness of enforcement actions, and maximise their impact and deterrent effect on market participants. Importantly, I concluded, ASIC must be well-resourced and willing to use these powers in order to promote public confidence and compliance with the law.

I was honoured to attend the 2016 Undergraduate Awards Global Summit and I encourage undergraduate students to continue to engage with the Undergraduate Awards in future. Not only may you come away from the experience with a sense of pride and enthusiasm about your research, but also (and perhaps more importantly) you might gain the opportunity to hear the views of students and presenters across multiple disciplines, and make new friends from all over the world!

3 Senate Economics References Committee, Parliament of Australia, Performance of the Australian Securities and Investments Commission (2014) xxi. 


\section{Bibliography}

Australian Securities and Investments Commission Act 2001 (Cth).

Senate Economics References Committee, Parliament of Australia. (2014). Performance of the Australian Securities and Investments Commission. Canberra, ACT: Senate Printing Unit.

Williams, Jacqueline. (2017). 'The Enforcement Regime of the Australian Securities and Investments Commission (ASIC) under Chapter 7 of the Corporations Act: Reform Required'. The Undergraduate Journal, 8, 113-120. 
This text is taken from The ANU Undergraduate Research Journal, Volume Eight, 2016, edited by Daniel McKay, published 2017 by ANU eView, The Australian National University, Canberra, Australia.

dx.doi.org/10.22459/AURJ.08.2016.01 